\title{
Aplikasi Terapi Bercakap - Cakap Pada Tn. N dengan Gangguan Persepsi Sensori: Halusinasi Pendengaran di Jampang Kulon
}

\author{
Siti Patimah ${ }^{1 *}$ \\ ${ }^{1}$ Universitas Muhammadiyah Sukabumi \\ E-mail: ${ }^{1}$ sitipatimah230@ummi.ac.id
}

\begin{abstract}
Abstrak
Masalah keperawatan jiwa yang mungkin muncul sebagai respon terhadap gangguan jiwa yang dialami oleh seorang individu diantarnya adalah risiko perilaku kekerasan, defisit perawatan diri, isolasi sosial dan gangguan persepsi sensori: halusinasi. Adapun halusinasi itu sendiri terdiri dari halusinasi pendengaran, halusinasi penglihatan, halusinasi perabaan, halusinasi pengecapan, dan halusinasi penghidu. Halusinasi pendengaran merupakan gangguan stimulus atau rangsangan dimana klien mendengar suara-suara tidak ada wujudnya terutama suara manusia, biasanya klien mendengar suara-suara orang sesuai dengan apa yang klien pikirkan yang kemudian memerintah klien untuk melakukan sesuatu yang kadang dapat membahayakan diri sendiri, orang lain, dan lingkungan. Dalam tahap pengkajian diperoleh data yang menunjukkan klien mengalami gangguan persepsi sensori: halusinasi pendengaran yaitu diperoleh dari faktor presipitasi klien sering mendengar suara-suara tanpa ada wujudnya disaat klien sendiri. Tn.N memiliki 4 masalah keperawatan diantaranya gangguan persepsi sensori: halusinasi pendengaran, risiko perilaku kekerasan, isolasi sosial dan harga diri rendah, namun penulis terfokus pada satu diagnosa yaitu ke masalah halusinasinya. Tindakan yang dilakukan yaitu melatih terapi bercakap - cakap dengan orang lain untuk menurunkan tingkat halusinasi pasien. Kesimpulan dari tindakan yang diberikan telah tercapai dimana klien sudah mampu bercakap - cakap dengan orang lain saat klien mengalami halusinasi.
\end{abstract}

Kata kunci: Terapi bercakap-cakap, Gangguan Persepsi Sensori, Halusinasi

\begin{abstract}
Problemsof mental health nursing that may arise in response to mental disorders experienced by an individual include the risk of violent behavior, self-care deficits, social isolation and impaired sensory perception: hallucinations. The hallucinations themselves consist of auditory hallucinations, visual hallucinations, tactile hallucinations, tasting hallucinations, and olfactory hallucinations. Auditory hallucination is a stimulus or stimulus disorder in which the client hears voices that do not exist, especially human voices, usually the client hears the voices of people according to what the client thinks which then orders the client to do something that can sometimes harm oneself, others, and the environment. In the assessment stage, data were obtained showing the client experiencing sensory perception disorders: auditory hallucinations, which were obtained from the precipitation factor. The client often heard voices without any form when the client was alone. Mr. $N$ has 4 nursing problems including sensory perception disorders: auditory hallucinations, risk of violent behavior, social isolation and low self-esteem, but the author focuses on one diagnosis, namely the problem of hallucinations. The action taken is to practice conversational therapy with other people to reduce the patient's level of hallucinations. The conclusion of the given action has been reached where the client is able to converse with other people when the client experiences hallucinations.
\end{abstract}




\section{Pendahuluan}

Kesehatan jiwa merupakan unsur utama yang mendukung kualitas hidup manusia. Jika seseorang dapat mengendalikan dirinya menghadapi stressor/masalah di lingkungan sekitarnya dengan selalu berfikir positif, maka ia dianggap sehat mentalnya (Muhith, 2011). Gangguan jiwa merupakan suatu keadaan yang tidak mudah untuk diketahui penyebabnya. Ada beberapa faktor yang saling berkaitan yang dapat menyebabkan seseorang mengalami gangguan jiwa, yaitu faktor kepribadian atau psikologi seseorang, cara berpikir dan kemampuan memecahkan masalah, gangguan otak, kondisi pengasuhan, tidak diterima oleh masyarakat, masalah dan kegagalan di dalam hidupnya. Faktor-faktor tersebut dapat menyebabkan gangguan jiwa pada seseorang. Namun faktor-faktor tersebut tidak dapat ada sendiri, akan menjadi satu-kesatuan dan menimbulkan gangguan jiwa secara bersamasama.

Menurut World Health Organization (WHO) tahun 2016, permasalahan gangguan jiwa di dunia saat ini telah menjadi masalah serius yang terus mengalami peningkatan. Dapat dikatakan bahwa seperempat penduduk di dunia ini menderita gangguan jiwa. WHO juga menyebutkan bahwa sekitar 450 juta orang di dunia dinyatakan menderita gangguan jiwa. Penderita gangguan jiwa mencapai $13 \%$ dan kemungkinan besar akan meningkat lagi beberapa tahun kedepan. Menurut data WHO (2016), penderita depresi sebanyak 35 juta jiwa, penderita bipolar sebanyak 60 juta jiwa, penderita skizofrenia sebanyak 21 juta dan penderita demensia sebanyak 4,7 juta jiwa.

Isue kesejahteraan emosional di Indonesia meluas pada tahun 2018 (Riskesdes 2018). Data dari Riset Kesehatan Dasar 2018 menunjukkan peningkatan yang ekstrim dalam kuantitas gangguan jiwa bila dibandingkan dengan Riskesdas 2013, yang naik 1,7\% menjadi $7 \%$. Peningkatan orang dengan gangguan jiwa terjadi saat ini diakibatkan karena adanya ketidakmampuan seseorang untuk menangani masalah kesehatan jiwa yang kemudian memunculkan gejala-gejala oleh penderita gangguan jiwa (Riskesdas, 2018).

Masalah keperawatan yang mungkin terjadi pada klien dengan masalah kesehatan kesehat jiwa adalah bahaya perilaku kekerasan yang berpotensi merugikan diri sendiri maupun orang lain. Isolasi sosial, lebih spesifiknya klien menjauh dari orang lain dan masalah persepsi sensori : halusinasi pendengaran, khususnya suara-suara yang muncul tanpa struktur atau tidak asli (Yosep, 2014).

Halusinasi adalah salah satu manifestasi dari masalah mental. Artinya, pasien mengalami perubahan persepsi sensori, perasaan palsu seperti ada suara, kadang-kadang seperti penglihatan, juga dapat berupa rasa, kontak atau bau. Pasien merasakan peningkatan atau hasutan yang tidak asli (Damaiyanti, 2012). Halusinasi yang terdengar oleh pasien berupa rangsangan dimana pasien mendengar banyak suara yang sebenarnya tidak ada, termasuk suara manusia. Pasien akan mendengar suara orang lain sesuai dengan apa yang dipikirkan pasien yang kemudian memerintahkan pasien untuk melakukan sesuatu yang dapat menyakiti dirinya sendiri, orang lain dan masyarakat (Prabowo, 2014).

Terapi yang bisa digunakan untuk mengendalikan halusinasi yaitu dengan mengenali halusinasi, terapi bercakap-cakap untuk mengalihkan halusinasi, pengobatan terencana untuk mengurangi visualisasi yang muncul, lebih spesifik melalui latihan setiap hari dan minum obat secara rutin untuk mengendalikan halusinasi yang timbul (Oky, 2015). Terapi bercakap-cakap merupakan salah satu cara untuk mengontrol klien yang mengalami halusinasi pendengaran. Beberapa penelitian telah membuktikan bahwa halusinasi dapat dikendalikan dengan cara bercakap-cakap atau mengobrol dengan orang lain. Klien yang mengalami halusinasi pendengaran akan mengalami pengalihan fokus dan perhatian dimana pikiran dan fokusnya akan beralih dari halusinasi pendengaran ke percakapan (Oky, 2015). Halusinasi pendengaran bisa berbahaya karena mempunyai perintah yang bisa 
membahayakan dirinya ataupun orang lain, seperti perintah membunuh dirinya, lari, perintah memukul orang dan juga tindakan kriminal lainnya (Lisa \& Giur, 2019). Terapi bercakap-cakap dapat mengontrol halusinasi. Dengan terapi bercakap-cakap halusinasi klien akan beralih ke percakapan yang klien lakukan dengan orang lain (Oky, 2015).

Di Wilayah Jampang kulon fasilitas kesehatan untuk gangguan jiwa sangat minim bahkan tidak ada pelayanan khusus yang melayani tentang gangguan jiwa, salah satunya Tn.N yang memiliki masalah halusinasi pendengaran belum ditangani dengan baik. Klien berada di rumah tanpa ada penanganan khusus dari petugas kesehatan terkait dengan tidak adanya fasilitas khusus untuk gangguan jiwa di wilayah tersebut.

Oleh karena itu, karena rasa ingin tahu yang besar juga untuk menambah wawasan dan pengalaman dalam penanganan pada pasien dengan masalah jiwa khususnya halusinasi pendengaran, maka penulis tertarik untuk melakukan studi kasus dengan judul "Aplikasi Terapi Bercakap-cakap Pada Tn.N Dengan Gangguan Persepsi Sensori : Halusinasi Pendengaran di Jampang Kulon".

\section{Metode Penelitian}

Metode yang digunakan oleh penulis dalam studi kasus ini adalah penelaahan kasus. Teknik pengambilan sampel yang dilakukan dalam studi kasus ini adalah total sampling yakni suatu teknik penetapan sampel dengan cara memilih sampel secara keseluruhan. Sampel yang diambil dalam studi kasus ini adalah satu orang dengan masalah halusinasi pendengaran di Wilayah Jampang Kulon. Lama kegiatan ini 1 bulan dengan 3 kali melakukan kunjungan rumah. Pengumpulan data dilakukan melalui observasi, melakukan wawancara langsung kepada klien, dan dokumentasi.

\section{Hasil}

Tn.N usia 35 tahun dengan diagnosa fokus gangguan persepsi sensori : halusinasi pendengaran. Faktor presipitasi klien mengatatakan sering mendengar suara tanpa ada wujudnya yaitu saat klien sendiri. Faktor Predisposisi pernah mengalami gangguan jiwa 5 tahun yang lalu setelah diceraikan oleh istrinya dan pernah masuk RS Jiwa, tidak memiliki trauma tetapi pernah menjadi pelaku memukuli ibunya, pengalaman tidak menyenangkan yaitu diceraikan oleh istrinya, pengobatan sebelumnya tidak berhasil karena tidak mau minum obat dan tidak ada keluarga yang mengalami gangguan jiwa.

\section{Pembahasan}

Masalah yang muncul terkait dengan halusinasi pendengaran yaitu di alam perasaan dimana klien sering mendengar suara tanpa ada wujudnya. Kemudian di persepsi yaitu klien mengatakan sering mendengar suara yang tidak ada objek suaranya, suara-suara itu muncul tidak menentu tetapi lebih sering muncul di malam hari ketika klien mau tidur. Frekuensinya 2-3x dalam sehari. Isi suara tersebut yaitu perintah seorang perempuan untuk memukul orang. Respon klien saat mengontrol halusinasinya yaitu dengan didiamkan. isi pikir yaitu Klien mengatakan pikirannya dipenuhi dengan bisikan perempuan untuk menuruhnya memukul orang. Dan di tingkat konsentrasi dan berhitung yaitu Tingkat konsentrasi klien mudah beralih, saat berbicara klien sering melirik kanan dan kiri seolah ada yang mengajak ia berbicara juga, klien kadang berbicara sendiri dan menutup telinga namun masih dapat berhitung sederhana dengan baik.

Dalam perencanaan penelitian yang terdapat dalam jurnal dikatakan bahwa perlu dilakukan pengenalan dan pengujian kelayakan terapi individu yang dilakukan dengan cara bercakap-cakap dalam rangka mengontrol halusinasi klien yang mengalami halusinasi pendengaran (Oky, 2015). Sedangkan dalam perencanaan ini penulis mengacu pada judul yaitu Terapi Bercakap-cakap Pada Tn.N dengan Gangguan Persepsi Sensori: Halusinasi Pendengaran yang telah disesuaikan dengan strategi pelaksanaan pada klien dengan 
halusinasi yaitu mengendalikan halusinasi dengan cara bercakap-cakap dengan orang lain. Yang dimulai dengan posisikan klien berhadap-hadapan dengan lawan bicara, jelaskan kepada klien tentang terapi bercakap-cakap, contohkan kepada klien memulai pembicaraan, praktekan dengan klien terapi bercakap-cakap dan anjurkan klien memasukan terapi bercakap-cakap dalam jadwal kegiatan harin.

Tindakan penulis pada klien bertujuan untuk meningkatkan kemampuan pengendalian halusinasi klien yaitu dengan cara membuat klien melakukan percakapan dengan orang lain. Dalam melakukan tindakan keperawatan ini, penulis mengacu pada intervensi keperawatan yang telah dibuat sebelumnya dan melakukan tindakan keperawatan mulai dari tanggal 1-3 Mei 2021. Penulis mengimplementasikan di hari pertama memposisikan klien berhadap-hadapan dengan lawan bicara, menjelaskan kepada klien tentang terapi bercakap-cakap, mencontohkan kepada klien memulai pembicaraan, mempraktekan dengan klien terapi bercakap-cakap dan menganjurkan klien memasukan terapi bercakapcakap dalam jadwal kegiatan harin. Di hari kedua dan ketiga mengevaluasi terapi bercakapcakap, mempraktekan kembali terapi bercakap-cakap dan mengajurkan klien memasukan aplikasi terapi bercakap-cakap dalam jadwal kegiatan harian. Hal yang sudah dapat dilakukan oleh klien yaitu : mampu mengendalikan halusinasi dengan terapi bercakapcakap dengan orang lain pada hari ketiga. Dalam melakukan evaluasi, ditemukan faktor pendukung terapi yaitu adanya kerjasama antara klien dan perawat yaitu klien kooperatif dalam melaksanakan rencana tindakan.

\section{Simpulan}

Data subjektif klien mengatakan sering mendengar suara yang tanpa ada wujudnya, suara itu muncul tidak menentu tetapi lebih sering muncul di malam hari ketika klien mau tidur. Frekuensinya 2-3x dalam sehari. Isi suara tersebut yaitu perintah seorang perempuan untuk memukul orang. Respon klien saat mengontrol halusinasinya yaitu dengan didiamkan. Data objektif saat berbicara klien sering melirik kanan dan kiri seolah ada yang mengajak ia berbicara, klien kadang berbicara sendiri dan menutup telinga. Diagnosa fokus yaitu gangguan persepsi sensori : halusinasi pendengaran. Terapi yang dilakukan yaitu terapi bercakap-cakap selama $3 x$ pertemuan dengan frekuensi 1-2x dan dengan durasi 10-15 tiap pertemuan. Terapi ini cukup efektif untuk mengontrol halusinasi yaitu pada hari ketiga.

\section{Referensi}

Damaiyanti, M. (2014). Asuhan Keperawatan Jiwa. Widya Medika

Oky, Fresa. (2015). Efektifitas Terapi Individu Bercakap-cakap Dalam Meningkatkan Kemampuan Mengontrol Halusinasi Pada Pasien Dengan Halusinasi Pendengaran. (http://ejournal.stikestelogororejo.ac.id/index.php/ilmukeperawatan/article/view/4 $\underline{37)}$

Lisa \& Giur. (2019). Manfaat Bercakap-cakap Dalam Peer Suport Pada Klien Dengan Gangguan Persepsi: Halusinasi Pendengaran. (http://jurnal.libakperngestiwaluyo.ac.id/ojs/index.php/jkanwvol82019/article/view/36)

Muhith, A. N. (2011). Terapi Modalitas Keperawatan Jiwa: Pengantar Teori. Salemba Medika

Prabowo, E. (2014). Konsep \& Aplikasi Asuhan Keperawatan Jiwa. Salemba Medika

Riset Kesehatan Dasar. (2018). Badan Penelitian dan Pengembangan Kesehatan Kementrian RI. (http://jurnal.unpad.ac.id) 
WHO. (2016). Masalah Gangguan Jiwa Di Dunia. (http://eprints.ums.ac.id/25898/11/08 naskah_publikasi.pdf)

Yosep, Iyus. 2014. Keperawatan Jiwa (Edisi Revisi). Salemba Medika 